\title{
MEKANISME SUARA TERBANYAK BAGI PEMILU LEGISLATIF (STUDI SIYASAH DUSTURIYAH)
}

\author{
Muhakki \\ Mahasiswa Aktif Pasca Sarjana (S2) IAIN Sunan Ampel Surabaya
}

\begin{abstract}
Abstrak; Studi ini ingin menjawab tiga permasalahan. Pertama, bagaimana pertimbangan yuridis dalam suara terbanyak?; Kedua, bagaimana implikasi yuridis suara terbanyak dalam Pemilu 2009?; Ketiga, bagaimana pandangan siyasah dusturiyah tentang mekanisme suara terbanyak?. Metode yang digunakan adalah pure legal, tipe yuridis normatif dengan pendekatan teori siyasah dusturiyah. Hasil temuan: Pertama, bahwa mekanisme nomor urut bertentangan dengan norma-norma atau dengan makna substantif kedaulatan dan persamaan hak bagi rakyat yang terkandung dalam UUD 1945, yang juga dibenarkan oleh prinsip-prinsip Syariat Islam; Kedua, mekanisme suara terbanyak dapat membatalkan sistem nomor urut (Pasal 2 I 4 UU 10/2008), suara terbanyak juga berpotensi memutus mata rantai oligarki, jual beli nomor urut dalam tubuh partai politik, membuka ruang ekspresi politik bagi warga negara, dan mendorong terjadinya pola hubungan timbal balik antara anggota legislatif dengan konstituenya, serta dapat meningkatkan kualitas keterwakilan anggota parlemen; Ketiga, mekanisme suara terbanyak memiliki efek positif yang lebih luas bukan orang perorangan ataupun kelompok, dan lebih mendekatkan pada Maslahah al-'Ammah, serta relevan atau lebih sesuai dengan tujuan syariat dengan mewujudkan Hifd al-ummah dalam kategori Hifd al-Nafs yaitu, hurriyah al-syahsiyah berupa hurriyah al-ra'y dan al-Musyawah, yaitu persamaan hak di muka hukum dan pemerintahan.
\end{abstract}

Kata Kunci: Siyasah dusturiyah, Mekanisme suara terbanyak, Pemilu Legislatif 2009.

\section{Pendahuluan}

Sejak reformasi Indonesia telah diramaikan dengan tuntutan atas hak hidup, hak atas kebebasan, dan hak kepemilikan, ${ }^{1}$ yang

I Meriam Budiarjo, Dasar-dasar Ilmu Politik, (Jakarta: Putaka Utama, 1972), 56. 
kemudian berimplikasi pada perubahan UUD 1945 dan Undangundang dibawahnya. Tak pelak perubahan terhadap mekanisme Pemilu pun harus dilakukan. ${ }^{2}$ Aturan main tentang Pemilu ${ }^{3}$ ini secara umum telah diatur dalam Bab VIIB pasal 22E UUD 1945 dan secara khusus dirumuskan dalam UU No. 12 tahun 2003 untuk Pemilu 5 April 2004 dengan sistem proporsional terbuka, sebagai perbaikan dari sistem pemilu 1999 dengan mekanisme proporsional daftar tertutup.

Pada pemilu 2004, $\mathrm{BPP}^{4}$ sebagai dasar penetapan calon Legislatif terpilih, dianggap sebagai terobosan baru yang dimaksudkan untuk mengakomodasi prinsip-prinsip sistem pluralitas-mayoritas (distrik) ke dalam sistem proporsional terbuka, dengan tujuan meningkatkan kedekatan wakil dengan rakyat yang diwakilinya.

Sedangkan bagi pemilu 2009, masalah BPP diatur dalam Pasal 214 UU 10/2008, yang menentukan bahwa calon terpilih adalah calon yang mendapat di atas 30\% (tiga puluh per seratus) dari BPP, atau menempati nomor urut lebih kecil, jika tidak ada yang memperoleh $30 \%$ (tiga puluh per seratus) dari BPP, atau yang menempati nomor urut lebih kecil jika yang memperoleh $30 \%$ (tiga puluh per seratus) dari BPP lebih dari jumlah kursi proporsional yang diperoleh suatu partai politik peserta Pemilu. ${ }^{5}$

\footnotetext{
${ }^{2}$ Titik Triwulan Tutik, Pokok-pokok Hukum Tata Negara, (Jakarta: Prestasi Pustaka, 2006), 289.

${ }^{3}$ Pemilu menjadi penting, karena mengandung beberapa argumentasi: Pertama, Pemilu adalah media artikulasi politik rakyat; Kedua, pemilu diselenggarakan dengan menggunakan dana yang tidak kecil; Ketiga, pemilu diselenggarakan untuk menjadi media bagi kontrak sosial antara rakyat dan pemimpinnya; Keempat, pemilu adalah cermin bagi tegaknya demokrasi dan hukum. Lihat: Agustb Riewanto, Ensiklopedi Pemilu; Analisis Kritis Instropektif Pemilu 2004 Menuju Agenda Pemilu 2009,(Yogyakarta: Fajar Pustaka, 2007), 9-II .

${ }^{4}$ BPP (Bilangan Pembagi Pemilihan) adalah bilangan pembagi yang diperoleh dari jumlah total suara sah dengan jumlah kursi yang tersedia disuatu daerah pemilihan (Dapil). Pasal 46 UU No. 12/2003 menyatakan bahwa Pemilu untuk memilih anggota DPR, DPRD provinsi dan DPRD Kabupaten/kota maupun DPD, masing-masing ditetapkan daerah pemilihannya.

${ }^{5}$ Lihat: Undang-undang Pemilu 2009; Undang-undang Republik Indonesia Nomor 10 Tahun 2008 Tentang Pemilihan Umum Anggota DPR, DPD dan DPRD.
} 
Aturan tersebut merupakan produk politik, sehingga tidak jarang Undang-undang bersifat multi tafsir dan kontradiktif. ${ }^{6}$ Faktanya, pasal 214 UU 10/2008 tentang Pemilu diajukan kepada MK untuk dilakukan uji materiil, oleh: Muhammad Sholeh, SH., dan juga oleh: Sutjipto, S.H., M.Kn, Septi Notariana, S.H., M.Kn, Jose Dima Satria, S.H., M.Kn. ${ }^{7}$

Untuk itu, MK menerima dan memutuskan bahwa sistem nomor urut tidak memiliki kekuatan hukum dan diganti dengan mekanisme suara terbanyak bagi pemenangan anggota legislatif pada pemilu 2009.8 Mekanisme ini tentu memiliki pertimbangan hukum, dan apabila dilaksanakan mesti memiliki implikasi, baik yang direncanakan atau yang diperkirakan maupun tidak, yang diharapkan ataupun tidak diharapkan. Pertimbangan hukum seperti ini, menurut al-Syatibi merupakan tujuan yang dikehendaki syara'. ${ }^{9}$ Apakah putusan itu berdampak positif (maslahat) atau negatif (mafsadat) bagi masyarakat.

Studi ini dimaksudkan untuk merespons mekanisme pemilu tersebut, dengan menitik beratkan pada pertimbangan normatif dan implikasi yuridis mekanisme pemenangan bagi pemilu legislatif. Hal ini dikaji melalui perspektif siyasah dusturiyah.

${ }^{6}$ Ramlan Surbakti, Perekayasaan Sistem Pemilihan Umum Untuk Pembangunan Tata Politik Demokratis, (Jakarta: Kemitraan, 2008), 2.

${ }^{7}$ Pemohon I mengajukan surat permohonan pada tanggal I September 2008 yang diterima dan terdaftar di Kepaniteraan Mahkamah Konstitusi pada tanggal 3 September 2008 dengan registrasi Nomor 22/PUU-VI/2008. Pemohon II mengajukan surat permohonan pada tanggal I September 2008 yang diterima dan terdaftar di Kepaniteraan Mahkamah pada tanggal 5 September 2008 dengan registrasi Nomor 24/PUU-VI/2008, yang telah diperbaiki dengan perbaikan permohonan bertanggal 24 September 2008 dan diterima di Kepaniteraan Mahkamah pada tanggal 25 September 2008, permohonan dimaksud oleh para Pemohon diperbaiki kembali dengan perbaikan permohonan pada tanggal 16 Oktober 2008 dan diterima di Kepaniteraan Mahkamah tanggal 16 Oktober 2008.

${ }^{8}$ Suara Karya, MK Kabulkan Uji Materill, Pemilu 2009 Gunakan Sistem Suara Terbanyak, 24/8/2008.

${ }^{9}$ Abu Ishaq al-Syatibi, al-Muwaffaqat fi Usul al-Syariah, (Beirut: Dar al-Kutub al-Ilmiyah, ttp), 837.

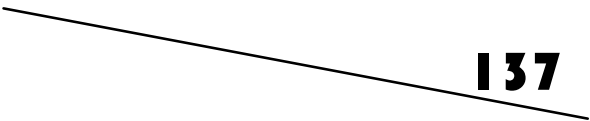




\section{Konsep Siyasah Dusturiyah}

Kata "dusturi" berasal dari bahasa Persia. Semula artinya adalah seseorang yang memiliki otoritas, baik dalam bidang politik maupun agama. ${ }^{10}$ Setelah mengalami penyerapan kedalam bahasa Arab, kata "dustur" berkembang pengertiannya menjadi asas, dasar atau pembinaan. Sedangkan menurut istilah, "dustur" adalah kumpulan kaidah yang mengatur dasar dan hubungan kerja sama antara sesama anggota masyarakat dalam sebuah Negara, baik yang tidak tertulis (konvensi) maupun yang tertulis (konstitusi). ${ }^{11}$

Menurut Abul A'la al-Maududi, "dustur"adalah "Saka Yantawi 'Ala al-Qawa'id al-'Asasiyah al-Lati Yaqumu 'Alayha Nidami Dawlah."12 Berdasarkan takrif ini, al-dusturi dapat dipahami sebagai suatu dokumen yang menjadi prinsip pokok dan landasan bagi pengaturan suatu Negara. Dengan demikian, kata "dustur" sama dengan constitution dalam bahasa Inggris, atau Undangundang Dasar dalam bahasa Indonesia. ${ }^{13}$

Bagi Abdul Wahhab Khallaf, al-dusturi merupakan prinsip dasar tentang bentuk suatu pemerintahan, aturan tentang hak-hak rakyat, dan pembagian kekuasaan. ${ }^{14}$ Mengenai bentuk pemerintahannya, Islam memberi kebebasan untuk memilih dan menentukan sendiri bentuk dan coraknya, asalkan tidak menyimpang dari prinsip-prinsip keadilan yang secara eksplisit diatur dalam syari'at. ${ }^{15}$ Artinya, Islam tidak menetapkan sistem

\footnotetext{
${ }^{10}$ Muhammad Iqbal, Fiqh Siyasah; Kontekstualisasi Doktrin Politik Islam, (Jakarta: Media Pratama, 2007), 153.

"lbid, I54.

${ }^{12}$ Abul A'la al-Maududi, Tadwin al-Dustur al-Islami, (Darul Fiqri, tt), 3.

${ }^{13}$ Istilah Konstitusi berasal dari Bahasa Perancis "Constituer" yang berarti membentuk. Sedangkan istilah UUD merupakan terjemahan istilah yang dalam bahasa Belanda-nya "Gronwet". Kata "wet" diterjemahkan ke dalam Bahasa Indonesia Undang-undang, dan "grond" berarti tanah/dasar. Dan dalam Bahasa Inggris dipakai istilah Constitution yang dalam Bahasa Indonesia disebut konstitusi. Lihat: Dahlan Thalib, dkk, Teori dan Hukum Konstitusi, (Jakarta: Raja Grafindo Persada, 1999), 7.

${ }^{14}$ Abdul Wahhab Khallaf,al-Siyasah al-Syar'iyah aw Nizam al-Daulah al-Islamiyah fi al-Syu'un alDusturiyah wa al-Kharijiyah wa al-Maliyah, (Kairo: Dar al-Anshar, 1977), 25.

15 Ibid, 25, 26.
} 
ketatanegaraan yang baku, hanya saja ada seperangkat tata nilai ${ }^{16}$ yang bersifat universal, ${ }^{17}$ yang dapat berperan penting dalam mengatur kehidupan bermasyarakat, yaitu untuk memelihara kemaslahatan sekaligus menghindari Mafsadat..$^{18}$

Prinsip dasar yang dimaksud adalah berkaitan dengan bentuk pemerintahan, aturan-aturan yang berkaitan dengan hak-hak rakyat, dan mengenai pembagian kekuasaan. ${ }^{19}$ Dengan demikian, fokus kajian siyasah dusturiyah adalah mengenai seluk-beluk pengaturan kepentingan umat manusia pada umumnya dan negara pada khususnya untuk mewujudkan kemaslahatan umat manusia sesuai dengan tuntunan Syariat.

Sedangkan dalil yang dapat dijadikan acuan bagi penyelenggaraan negara adalah Firman Allah Q.s. al-Syura: 38. Ayat ini, menurut penjelasan Muhammad Asad, bahwa kata "'Amr" yang digunakan menunjukkan semua urusan yang bersifat kemasyarakatan..$^{20}$ Sedangkan ayat "'Amruhum Shura Baynahum," secara harfiyah berarti urusan kemasyarakatan yang di musyawarahkan di antara mereka, bukan saja menjadikan pemecahan semua masalah politik sebagai hasil musyawarah, tetapi sama artinya dengan musyawarah itu sendiri. Sedangkan isi ayat "di antara mereka" menunjukkan seluruh jamaah (rakyat), yang mempunyai relevansi dengan majelis perundang-undangan atau Majelis Syura. ${ }^{21}$

${ }^{16}$ Munawwir Sjadzali, Islam dan Tata Negara: Ajaran, Sejarah, dan Pemikiran, (Jakarta: UI Press, 1993), I-2.

${ }^{17}$ Nilai-nilai Universal Islam tercermin dalam syariat yang dipahami sebagai hukum tertinggi: Qs. al-Jats|iyah: 18. Menurut Ulama usul fiqh, syariat adalah teks-teks kalamullah yang bersifat Syar'i (hukum). Namun apabila ada permasalahan hukum dan jawabannya tidak diatur secara eksplisit dalam Syariat, maka dilakukan ïtihad. Lihat: Beni Ahmad Saebani, Filsafat Hukum Islam, (Bandung: Pustaka Setia, 2007), 37.

${ }^{18}$ Fathurrahman Djamil, Filsafat Hukum Islam, (Jakarta: Logos, 1999), 125.

19 Dahlan, (ed), Ahmad Sukarja, Ensiklopedi Tematis Dunia Islam, Fikih Siyasah, ttp. (Ajaran: Ichtiar Van Hoeve, 200 I), 1659.

${ }^{20}$ Abdul Qadir Djaelani, Negara Ideal Menurut Konsepsi Islam, (Surabaya: Bina IImu, 2005), 196.

21 Majelis syura dalam pemikiran Tata Negara Islam dikenal dengan istilah "Ahl al-Hall wa al-'Aqd". Abu A'la al-Maududi menyebut sebagai dewan penasehat. Lihat: Ibid, hal, 197. Abdul Wahhab Khallaf memberikan klasifikasi: Pertama, Sultah tasyriliyyah (lembaga legislatif); Kedua, Sultah tanfiziyyah (lembaga eksekutif); dan Ketiga, Sultah qad\{a'ilyyah (lembaga yudikatif). Pada awal

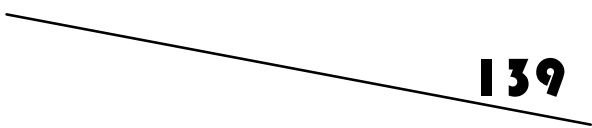


Selain itu, hak-hak Umat juga menjadi fokus kajian Siyasah dusturiyah, karena keberadaan perundang-undangan dan lembaga selalu diorientasikan pada hak-hak umat. Bahkan Al-Maududi menyakatan bahwa, Umat sebagai warga Negara memiliki sekian banyak hak yang harus dihormati dan dihargai oleh orang lain. Agar hak-hak tersebut benar-benar dapat dilindungi oleh pemerintah, sehingga perlu diatur atau dicantumkan dalam Undang-undang Dasar Negara. ${ }^{22}$

Hak-hak yang harus diakomudasi itu terdiri dari 2 (dua) macam hak. Pertama, hak-hak asasi manusia (hurriyah al-syahsiyah), seperti jaminan keselamatan dan perlindungan atas kehidupan pribadi (hurriyah al-fardiyah aw hurriyah al-dhat), tempat tinggal (hurriyah al-ma'wa), pemilikan (hurriyah al-milkiyah), kebebasan untuk memeluk agama (hurriyah al-I'tiqad), mengeluarkan pendapat (hurriyah al-ra'y), hak untuk mendapatkan pendidikan dan pengajaran (hurriyah al-ta'lim). Kedua, hak untuk mendapatkan persamaan (al-musyawah) di muka hukum dan pemerintahan. ${ }^{23}$ Perlindungan terhadap hak-hak inilah yang memiliki relevansi dengan kata "maslahah", yang sinonim dengan kata manfaat dan antonim dengan kata "Mafsadah" (kemudaratan).

Secara umum Maslahah berarti menarik Maslahah dan menolak Mafsadah, ${ }^{24}$ dan sederhananya, dapat diartikan sebagai sesuatu yang baik dan dapat diterima oleh akal sehat. Ibnu 'Aqil

Islam, ketiga kekuasaan ini, tidak terpisah tetapi berada pada satu tangan, yaitu kepala Negara. Pada masa berikutnya, ketiga lembaga kekuasaan tersebut masing-masing melembaga dan mandiri. Lihat: Sukarja, Ensiklopedi, 198.

22 Al-Maududi, al-Khilafah wa al-Muluk, (Kuwait: Dar al-Qalam, 1978), 66-70. Lihat juga: Abdul Wahhab Khallaf, al-Siyasah al-Syar'iyah aw Nizam al-Daulah al-Islamiyah fi al-Syu'un alDusturiyah wa al-Kharijiyah wa al-Maliyah, 30-42.

${ }^{23}$ Hak warga negara yang dimaksud adalah hak untuk mendapatkan persamaan kedudukan dalam hukum dan pemerintahan; hak untuk mendapatkan pekerjaan dan penghidupan yang layak; hak untuk berserikat, berkumpul, dan mengeluarkan pendapat, baik lisan maupun tulisan; hak kemerdekaan untuk memeluk agama; hak untuk mendapatkan pendidikan dan pengajaran; dan hak untuk mendapatkan kesejahteraan sosial. Lihat: Ibid, hal, 49. Lihat juga: Ahmad Sukarja, Ensiklopedi Tematis Dunia Islam, 198.

${ }^{24}$ Abdul Manan, Reformasi Hukum Islam Di Indonesia,(Jakarta: Raja Grafindo Persada, 2006), 261 . 
menyatakan sebagaimana dikutif oleh Ibn al-Qayyim, bahwa maslahah ini sebagai segala perbuatan yang membawa manusia lebih dekat kepada kemaslahatan dan lebih jauh dari kemafsadatan (keburukan), sekalipun Rasulullah tidak menetapkan dan (bahkan) Allah SWT tidak menentukannya. ${ }^{25}$ Namun prinsip maslahah ini harus sesuai dengan tujuan pencipta hukum (Syari') dalam menetapkan kebahagiaan manusia seluruhnya, baik di dunia yang fana (sementara), maupun di akhirat yang kekal $\left(B a q a^{\prime}\right) .{ }^{26}$

Untuk penerapan dalil Maslahah ini, Imam Maliki mengajukan tiga syarat: ${ }^{27}$ Pertama, Adanya persesuaian antara maslahah yang dipandang sebagai sumber dalil yang berdiri sendiri dengan tujuan-tujuan Syariat. Artinya, maslahah tidak boleh menegasikan sumber dalil yang lain, atau bertentangan dengan dalil yang qat'iy (al-Qur'an). Kedua, Harus masuk akal (rationable), mempunyai sifat-sifat yang sesuai dengan pemikiran yang rasional, andaikan diajukan kepada kelompok rasionalis maka akan diterima. Ketiga, Penggunaan dalil maslahah dalam rangka menghilangkan kesulitan yang mesti terjadi.

Menurut Ulama' Ushul, Maslahah adalah "Memberikan hukum syara' kepada suatu kasus yang tidak terdapat di dalam Nash dan ijma' atas dasar memelihara kemaslahatan yang tidak ditegaskan oleh syara' dan tidak pula ditolak". ${ }^{28}$ Bahkan menurut al-Syatibi, al-maslahah telah menjadi ijma' Ulama', karena Allah

${ }^{25}$ Djazuli, Fiqh Siyasah, 26-27. Pada prinsipnya maslahah adalah kristalisasi dari nilai universal Syariat, dalam Firman Allah QS. al-Anbiyaa': 107. Ayat ini menurut al-Syatibi menunjukkan bahwa syari'at yang dimaksudkan oleh Allah adalah maslahah al-'Amm. Lihat: Abu Ishaq alSyatibi, al-Muwaffaqat fi Usul al-Syari'ah, (Beirut: Dar al-Kutub al-Ilmiyah, ttp), 220.

26 Suparman Usman, Hukum Islam; Asas-asas dan Pengantar Studi Hukum Islam dalam Tata Hukum Indonesia, (Jakarta: Gaya Media Pratama, 200I), 65-66.

27 Muhamad Abu Zahroh, (et. Al), Saefullah Ma'shum, dkk, Usul Fiqh, (Jakarta: Pustaka Firdaus, 2007), 427-428.

${ }^{28}$ A. Dzazuli, Nurol Aen, Ushul Fiqh; Metodologi Hukum Islam, (Jakarta: Raja Grafindo Persada, 2000), 17I. Ada suatu pemahaman tentang maslahah, bahwa setiap suruhan Allah dapat dipahami oleh akal, kenapa Allah menyuruh, yaitu karena mengandung kemaslahatan untuk manusia baik dijelaskan sendiri alasannya oleh Allah atau tidak. Lihat: Amir Syarifuddin, Ushul Fiqh, Jilid 2, (Jakarta: Kencana, 2008), 207.

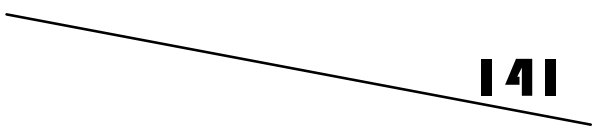


sebagai syari' bertujuan untuk mewujudkan al-maslahah al'Ammah.'29

Lebih lanjut, Al-Syatibi mengklasifikasi dan membagi maslahah kedalam tiga tingkatan: ${ }^{30}$ Pertama, kemaslahatan primer (al-dhururiyah), yaitu kemaslahatan yang mesti menjadi acuan utama bagi implementasi syariat. Yang masuk kategaori ini adalah melindungi Agama (Hifd al-din), melindungi jiwa (Hifd al-Nafs), melindungi akal (Hifd al-'Aql), melindungi keturunan (Hifd alNasl), dan melindungi harta (Hifd al-Mal). Kedua, kemaslahatan sekunder, yaitu kemaslahatan yang tidak menyebkan rusaknya tatanan sosial dan hukum, melainkan sebagai upaya untuk meringankan bagi pelaksanaan sebuah hukum. Ketiga, kemaslahatan suplementer, yaitu kemaslahatan yang memberikan perhatian pada masalah estetika dan etika. Kemaslahatan ini dimaksudkan untuk menyempurnakan kedua kemaslahatan, yaitu yang bersifat primer dan sekunder. Uraian ini juga diperkuat oleh Ibn 'Asyur, dengan mengklasifikasi maksud syari', antara lain: alhikmah, al-maslahah, dan al-manfaah. ${ }^{31}$

\section{Mekanisme Pemenangan Pemilu Legislatif 2009}

Berdasarkan putusan Mahkamah Konstitusi ${ }^{32}$ No. 22-24/PUUVI/2008, Uji materiil terhadap pasal 214 UU 10/2008 tentang pemilu, yang mengatur tentang pemenangan Anggota Legislatif berdasarkan nomor urut (capaian suara $30 \%$ dari BPP), diganti dengan mekanisme suara terbanyak bagi pemilu 2009.

\footnotetext{
${ }^{29}$ Abu Ishaq al-Syatibi, al-Muwafaqat fi Ushul al-Syari'ah, 20.

30 lbid., 3, 23.

${ }^{31}$ Gagasan Ibn 'Asyur lebih menekankan pada Maqhasyid al-Syari'ah, yang ditegaskan sebagai yang dikehendaki syara', yaitu merealisasikan maslahah al-'Ammah dengan menerapkan ketentuan hukum yang mengandung al-hikmah. Lihat: Muhammad Thahir Ibn 'Asyur, Maqasyid al-Syari'ah al-Islamiyah, (Dar al-Mafa'is li al-Nasyr wa al-Tawzi, 200 I), 273, 147.

32 Dasar Hukum kewenangan Mahkamah Konstitusi adalah Pasal 24C ayat (I) perubahan ketiga UUD 1945 juncto Pasal 10 UU No. 24/ 2003, Mahkamah konstitusi berwenang mengadili pada tingkat pertama dan terakhir yang putusannya bersifat final, berwenang untuk: Menguji Undang-undang terhadap Undang-Undang Dasar 1945; Memutus sengketa kewenangan lembaga Negara yang kewenangannya diberikan oleh Undang-undang Dasar; Memutus pembubaran partai politik, dan; Memutus perselisihan tentang hasil pemilihan umum.
} 
Penerapan pasal 214 tersebut, berdasarkan keterangan para pemohon, yaitu pemohon I (satu) dan II (dua) yang pada prinsipnya menyatakan, bahwa apabila mereka dipilih dan suara yang didapat tidak mencapai $30 \%$ (tiga puluh per seratus) dari BPP maka akan menjadi sia-sia, meskipun mereka mendapat suara terbanyak, karena berada pada nomor urut besar. ${ }^{33}$

Dengan demikian, Hak konstitusional mereka (hak-hak yang dijamin oleh UUD) sebagai Caleg dirugikan dengan berlakunya pasal 214 UU 10/2008 tersebut. Oleh karenanya, sistem nomor urut seharusnya diganti menjadi: "Calon terpilih anggota DPR, DPRD propinsi dan DPRD kabupaten/kota ditetapkan berdasarkan perolehan suara terbanyak dalam satu partai politik pada satu daerah pemilihan", sehingga ada perlakuan yang adil dan tidak ada diskriminasi.

Keterangan di atas, berbeda dengan keterangan DPR, yang menyatakan bahwa ketentuan pasal 214 bukan merupakan persoalan konstitusionalitas Undang-Undang Pemilu. Bahkan secara konstitusional sesungguhnya tidak terdapat kerugian konstitusional bagi para Pemohon, karena diberlakukan untuk semua partai politik peserta Pemilu dan semua bakal calon Legislatif. ${ }^{34}$

Begitu juga menurut Pemerintah, bahwa pasal 214 tidak menimbulkan kerugian hak dan/atau kewenangan konstitusional bagi Caleg, karena pada kenyataannya keberadaan para Pemohon untuk melaksanakan hak-hak konstitusionalnya sebagaimana yang dijamin oleh konstitusi tidak terganggu, terkurangi maupun terhalang-halangi atas berlakunya ketentuan tersebut, justru telah menciptakan perlakuan yang adil dan mewujudkan kepastian hukum (rechtszekerheid) terhadap para calon anggota Legislatif (Caleg) DPR maupun DPRD propinsi atau Kabupaten/Kota.

Selanjutnya pihak Komisi Pemilihan Umum (KPU) memberi keterangan, bahwa implementasi Pasal 214 secara teknis di

\footnotetext{
${ }_{33}^{3}$ Putusan MK No. 22-24/PUU-VI/2008.

${ }^{34}$ Ibid.
}

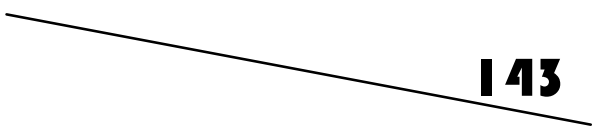


lapangan tidak ada persoalan yang cukup signifikan. Namun berdasarkan Pemilu Tahun 2004 dan prediksi Tahun 2009, sangat mungkin dapat menimbulkan persoalan cukup serius menyangkut masalah stabilitas politik di tingkat lokal, ${ }^{35}$ yaitu timbulnya problem-problem internal partai politik, baik bagi calon yang akan diganti maupun calon yang akan menggantikan.

Sedangkan menurut Mahkamah, bahwa dalam setiap negara yang menyatakan dirinya sebagai negara hukum yang demokratis, akan selalu terjadi tarik menarik antara dua kepentingan yang sama-sama fundamental. Konsekuensinya, sebagaimana yang ditegaskan oleh Pasal 1 ayat (2) dan ayat (3) UUD 1945, tidak hanya berarti bahwa proses pembentukan hukum dan materi muatannya harus mengindahkan prinsip-prinsip demokrasi, tetapi juga berarti bahwa praktik demokrasi harus tunduk pada prinsip negara hukum (rechtsstaat, rule of law) yang menempatkan UUD 1945 sebagai hukum tertinggi (supreme law). ${ }^{36}$

Dengan alasan tersebut, Mahkamah berpendirian bahwa setiap undang-undang adalah konstitusional (principle of constitutionality) sampai terbukti melalui proses peradilan bahwa Undang-undang yang bersangkutan inkonstitusional, apabila bertentangan dengan makna substantif kedaulatan rakyat dan bertentangan dengan prinsip keadilan sebagaimana diatur dalam Pasal 28D ayat (1) UUD 1945.

Apabila suatu UU dapat menghilangkan hak-hak konstitsional, maka merupakan pelanggaran atas kedaulatan rakyat, jika kehendak rakyat yang tergambar dari pilihan mereka tidak diindahkan dalam penetapan anggota legislatif akan benarbenar melanggar kedaulatan rakyat dan keadilan, jika ada dua orang calon yang mendapatkan suara yang jauh berbeda secara ekstrem dan calon yang mendapat suara banyak dikalahkan oleh calon yang mendapat suara kecil, karena yang mendapat suara kecil nomor urutnya lebih kecil. 
Apalagi Indonesia saat ini telah menganut sistem pemilihan langsung untuk Presiden dan Wakil Presiden, Dewan Perwakilan Daerah, dan Kepala Daerah dan Wakil Kepala Daerah, sehingga menjadi adil jika pemilihan DPR/DPRD juga bersifat langsung memilih orang tanpa mengurangi hak-hak politik parpol, sehingga setiap calon anggota legislatif dapat menjadi anggota legislatif pada semua tingkatan sesuai dengan perjuangan dan perolehan dukungan suara masing-masing. Oleh karenanya, Pasal 214 UU 10/2008 mengandung standar ganda sehingga dapat dinilai memberlakukan hukum yang berbeda terhadap keadaan yang sama sehingga dinilai tidak adil.

Dengan putusan MK yang menyimpulkan pasal 214 UU 10/2008 inkonstitusnal, ${ }^{37}$ maka sistem nomor urut telah dibatalkan keberlakuaannya dan diganti dengan mekanisme suara banyak bagi Pemilu 2009. Penerapan sistem ini, tentunya berpengaruh terhadap perolehan suara, khususnya bagi kemenangan setiap Caleg yang ikut kontestasi pada pemilu 2009.

Berdasarkan penetapan KPU tentang hasil pemilihan umum anggota DPR 2009 setelah 14 hari, yaitu 26 April - 9 Mei 2009, yang melaksanakan rekapitulasi penghitungan suara secara nasional. ${ }^{38}$ Hasil yang diumumkan meliputi perolehan suara dan jumlah kursi masing-masing parpol di DPR Republik Indonesia. Penetapan jumlah kursi tersebut, kemudian direvisi oleh KPU pada tanggal 13 Mei 2009 setelah terjadi perbedaan pendapat mengenai metode penghitungannya.

${ }^{37}$ Inkonstitusionalitas UU yang diputuskan pengadilan (MK) bukan hanya sudah diratifikasi suara mayoritas, tetapi sudah dikaji secara teori, dan sekaligus perihal kesesuaian dengan konstitusi. Pelaksanaan putusan pengadilan ini, sebenarnya Mahkamah sedang berhadapan dengan keputusan dua cabang pemerintahan yang lain, yaitu legislatif dan eksekutif. Lihat: W. Levy, (et.), Judicial Review: Sejarah Kelahiran, Wewenang dan Fungsinya dalam Negara Demokrasi, (Jakarta: Media Pratama, 2008), 87.

38 Penetapan perolehan suara dalam Pemilu dari total pemilih terdaftar sebanyak 171.265.44। pemilih. Sedangkan pemilih yang menggunakan hak pilihnya sebanyak I21.588.366, sementara sebesar 49.677.075 tidak menggunakan hak pilihnya. Pemilih yang telah menggunakan hak pilihnya dan dianggap tidak sah sebesar 17.488.581, dan pemilih yang menggunakan hak pilinnya secara sah adalah sebanyak 104.099.785 suara. Data ini didasarkan pada pengumuman dari KPU Pada Tanggal 9 Mei 2009 s/d I 4 Mei 2009.

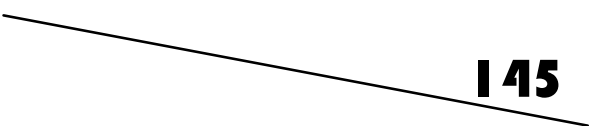


Dari 38 parpol yang ikut kontestan dalam pemilu 2009, hanya 9 (sembilan) parpol yang berhasil lolos dari Parliamentary threshold (sistem pemilihan terbuka). Beberapa parpol yang memperoleh suara dengan mencapai 2,5 atau lebih ditingkat nasional adalah:

\begin{tabular}{|l|c|c|c|c|}
\hline \multirow{2}{*}{ Partai Politik } & \multicolumn{2}{c|}{ Suara } & \multicolumn{2}{c|}{ Kursi } \\
\cline { 2 - 5 } & Jumlah & Persen & Jumlah & Persen \\
\hline Partai Demokrat & 21.703 .137 & 20,85 & 150 & 26,79 \\
\hline Partai Golkar & 15.037 .757 & 14,45 & 107 & 19,11 \\
\hline PDIP & 14.600 .091 & 14,03 & 95 & 16,96 \\
\hline PKS & 8.206 .955 & 7,88 & 57 & 10,18 \\
\hline PAN & 6.254 .580 & 6,01 & 43 & 7,68 \\
\hline PPP & 5.533 .214 & 5,32 & 37 & 6,61 \\
\hline PKB Gerakan & 5.146 .122 & 4,94 & 27 & 4,82 \\
\hline $\begin{array}{l}\text { Partai } \\
\text { Indonesia Raya }\end{array}$ & 4.646 .406 & 4,46 & 26 & 4,64 \\
\hline Partai HANURA & 3.922 .870 & 3,77 & 18 & 3,21 \\
\hline
\end{tabular}

SUMBER: KPU tanggal 9, 11 dan 14 Mei 2009.

Partai Demokrat meskipun masih tergolong sebagai partai politik yang relatif baru, namun pada pemilu 2009 ini dapat dikatakan memiliki prestasi yang prestisius. Pada pemilu 2004 partai demokrat hanya meraih $7,46 \%$ atau 8.437 .868 , kini suaranya melonjak hampir tiga kali lipat menjadi 20,85\% atau 21.703.137. Bahkan juga mampu menempatkan Caleg-calegnya hingga 26,79 \% atau berhak mendapatkan 150 kursi di parlemen.

\section{Kualifikasi Norma-Norma dalam Mekanisme Suara Terbanyak}

Dasar hukum mekanisme suara terbanyak adalah konstitusi UUD 1945, yang digunakan untuk menjaga kedaulatan rakyat dan mengupayakan keadilan secara konstitusional bagi rakyat. Indonesia sebagai negara penganut sistem domokrasi, semua bidang kekuasaanya dipusatkan pada rakyat, dan dijalankan oleh lembaga yang para anggotanya dipilih oleh rakyat dan secara 
hukum harus bertanggung jawab kepada rakyat. ${ }^{39}$ Artinya, menggunakan prinsip pembagian kekuasaan agar terjadi keseimbangan (check and balances) dalam pelaksanaan kekuasaan.

Pembagian kekuasaan tersebut mengacu pada konstitusi ${ }^{40}$ yang mengandung norma-norma ${ }^{41}$ tentang hak-hak rakyat, yang selanjutnya disebut dengan hak konstitusional, khususnya hakhak untuk mendapatkan persamaan kedudukan dalam hukum (pasal 27 ayat (1), pasal 28D ayat (1) UUD 1945) dan hak dalam pemerintahan (pasal 28D ayat (3) UUD 1945), dalam konteks ini adalah hak untuk memilih dan dipilih sebagai anggota DPR/DPRD.

Sedangkan mekanisme nomor urut (pasal 214 UU 10/2008 Tentang pemilu) berimplikasi pada tidak terpilihnya caleg menjadi anggota legislatif, meskipun caleg itu mendapat suara terbanyak, tapi mereka berada dalam nomor urut besar. Dengan demikian, penentuan kemenangan anggota Legislatif yang didasarkan pada nomor urut berpotensi menghilangkan hak konstitusional mereka. Artinya, hak-hak mereka (pemohon) sebagai caleg yang dijamin oleh konstitusi, yaitu hak persamaan dimuka hukum dan pemerintahan dirugikan atas pemberlakuan sistem nomor urut.

${ }^{39}$ Suatu lembaga kekuasaan negara yang dipilih oleh rakyak disebut organ kologial. Lihat: Hans Kelsen, Teori Umum Tentang Hukum dan Negara,alih bahasa, Raisul Muttaqien, (Bandung: Nusa Media \& Nuansa, 2006), 339-4000.

${ }^{40}$ Fungsi dan kedudukan konstitusi: (a)sebagai dokumen nasional yang mengandung perjanjian luhur, berisi kesepakatan-kesepakatan tentang politik, hukum, pendidikan, kebudayaan, ekonomi, kesejahteraan, dan aspek fundamental yang menjadi tujuan Negara; (b) sebagai piagam kelahiran baru atau sebagai bukti adanya pengakuan masyarakat internasional; (c) sebagai sumber hukum tertinggi; (d) sebagai identitas nasional dan lambang persatuan; (e) sebagai alat untuk membatasi kekuasaan; (f) sebagai pelindung HAM dan kebebasan warga Negara.

${ }^{41}$ Norma dalam Kamus Besar Bahasa Indonesia adalah aturan atau ketentuan yang mengikat warga kelompok dalam masyarakat, dipakai sebagai panduan, tatanan, dan pengendalian tingkah laku setiap masyarakat. Lihat: Depdiknas, Kamus Besar Indonesia, (Jakarta: Gramedia Pustaka Utama, 2008), h. 968. Menurut Hans Kelsen, "Norma" adalah sesuatu yang seharusnya ada atau seharusnya terjadi, khususnya manusia harus berperilaku dengan cara tertentu, yang secara tatanan hukum disebut dengan "Norma Dasar" (Grundnorm). Lihat: Hans Kelsen, Teori Hukum Murni; Dasar-dasar Ilmu Hukum Normatif, alih bahasa, Raisul Muttaqin, (Jakarta: Nusa Media, 2008), 5, 10. Norma-norma tentang hak-hak rakyat dalam konteks Indonesia terkandung dalam Pasal 27 ayat (I), Pasal 28D ayat (I), dan Pasal 28E ayat (2) UUD 1945.

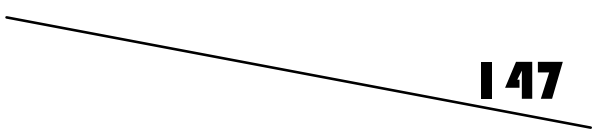


Hak-hak seperti yang terkandung dalam konstitusi itu dalam siyasah dusturiyah juga menjadi hal penting yang harus dilindungi, bahkan setiap individu pun dilihat sebagai orang yang memiliki hak yang sama, sehingga layak untuk mendapatkan kedudukan dan diperlakuan sama di muka hukum, ${ }^{42}$ termasuk hak politik mereka. ${ }^{43}$

Pasal 214 UU 10/2008 tentang pemilu sebanarnya juga dirumuskan oleh lembaga negara yang juga memiliki makna "harus" dan makna "obyektif" yakni, makna dari sebuah norma yang "sah" dari tindak legislasi dengan karakter norma yang bersifat mengikat, ${ }^{44}$ namun posisinya berada dibawah UUD 1945. Artinya, apabila terjadi perbedaan mengenai tafsir ${ }^{45}$ terhadap suatu UU, maka harus diuji dengan konstitusi utama tersebut. Seperti pertentangan antara Pemerintah, DPR, KPU, dan Para pemohon tentang pasal 214 UU 10/2008, yang kemudian diputus oleh MK sebagai UU yang inkonstitusional.

Masalah perbedaan ${ }^{46}$ penafsiran atau jurisdiksi dalam masalah peraturan tersebut, berdasarkan kaidah: "Hukm al-Hakim

${ }^{42}$ Samir Aliyah, Sistem Pemerintahan Peradilan dan Adat dalam Islam, alih bahasa, Asmuni Solihan Zamakhsyari, ( Jakarta: KHALIFA, 2004), 77.

${ }^{43}$ Al-Mawardi, al-Ahkam as-Sulthaniyah, alih bahasa, Fadli Bahri, (Jakarta: Darul Falah, 2007), 25.

${ }^{44}$ Hans Kelsen, Teori Hukum Murni, 10.

45 Perbedaan penafsiran merupakan persoalan tentang penalaran hukumyang mana dalam istilah hukum disebut "publik opinion" (pendapat umum). Lihat: Yan Pramadya PUSPA, Kamus Hukum, (Semarang: Aneka Ilmu, 1977), 693.

${ }^{46}$ Pemerintah, DPR, dan KPU berpandangan bahwa pasal 214 UU 10/2008 tidak bertentangan dengan norma-norma konstitusi. Para pemohon memandang sebagai aturan yang diskriminatif, karena merugikan hak konstitusional mereka. Sedangkan MK menyimpulkan sebagai aturan yang memiliki standar ganda, sehingga inkonstitusional. Lihat: Putusan MK No. 22-24/PUUVI/2008. Perbedaan pendapat seperti ini, dalam konteks siyasah dusturiyah dikembalikan kepada hukum tertinggi, yaitu syari'at, Firman Allah, Q.s. An-Nisa': 59. Maksud Ayat, apabila terjadi perselisihan atau perkara antara warga negara dengan para penguasa, maka harus dikembalikan kepada Allah dan Rasul-Nya. Lihat: Khalid Ibrahim Jindan, Teori Politik Islam; Telaah Kritis Ibnu Taimiyah Tentang Pemerintahan Islam, h. 66. Bahkan Ibnu Taimiyah menyebut sebagai pelecehan terhadap supremasi hukum, apabila sikap dari pemegang kekuasaan dan sebagian dari pihak pemerkara itu sendiri yang tidak mengetahui, tidak menerapkan yang seharusnya dengan benar dan berlaku zalim kepada rakyat sebagai pencari keadilan, karena penerapan materi hukum itu tidak sesuai dengan makna asalnya. Lihat: Ibnu Qayyim al-Jauziyah, (et.), Muhammad Jamil Ghozi, Hukum Acara Peradilan Islam, alih bahasa,Adnan Qohar dkk, 178. 
Fi Masa'il al-Ijtihad Yarfa'u al-Khilaf". ${ }^{47}$ Maksud kaidah, bahwa Syari' satu-satunya bagi umat Islam adalah Allah SWT.48 Sedangkan maksud syari' adalah hikmah, maslahah, dan manfaat. Dengan kata lain, tujuan umum syariat adalah kemaslahatan umat, karena hal ini yang dikehendaki syara' ${ }^{49}$

Oleh karena sistem nomor urut dapat menghilangkan hakhak konstitusional rakyat, sehingga dinilai bertentangan dengan UUD 1945. Sedangkan norma-norma yang tercamtum dalam konstitusi tersebut dibenarkan atau tidak bertentangan dengan Syara'. Dengan demikian, mekanisme nomor urut juga dapat dinilai bertentangan dengan Syariat.

\section{Implikasi mekanisme suara terbanyak}

Sebelum menganalisa lebih jauh tentang mekanisme suara terbanyak, sebagai bahan pertimbangan akan diuraikan juga tentang implikasi sistem nomor urut. Kendatipun sistem pemilu 2004, ${ }^{50}$ merupakan perbaikan dari pemilu 1999, tetapi peluang untuk mengubah keterpilihan kandidat dalam daftar parpol tidak cukup berdaya-guna.

Dari 550 kursi DPR, misalnya hanya 0,36 persen ( 2 orang) yang terpilih melalui BPP dan sebanyak 548 orang $(99,64 \%)$

${ }^{47}$ A. Djazuli, Kaidah-kaidah Fikih; Kaidah-kaidah Hukum Islam dalam Menyelesaikan Masalahmasalah yang Praktis, I54. Mengenai syara', dikalangan para ulama tidak ada perselisihan pendapat bahwa syara' itulah yang menjadi hakim sesudah Rasul dibangkitkan dan sesudah sampai seruannya kepada yang dituju. Lihat: Miftahul Arifin \& Faishal Haq, Ushul Figh I, (Surabaya: Biro Penerbitan dan Pengembangan Fakultas Syari'ah IAIN Sunan Ampel, 1995), 17.

${ }^{48}$ Maksud dari kaidah di atas bahwa putusan hukum yang tetap tidak bisa ditolak dengan alasan ada pendapat lain yang berbeda dengan ijtihad hakim, dengan syarat tidak keluar dari prinsipprinsip syariat. Sifat putusan adalah tetap dan tidak ada peluang usaha hukum lain yang bisa mengubah keputusan tersebut. Lihat: Syarifuddin Amir, Ushul Fiqh I, Jakarta: Logos Wacana Ilmu, 1997), 347.

${ }^{49}$ Muhammad Thahir Ibn 'Asyur, Maqhasyid al-Syariah al-Islamiyah, (Dar al-Mafa'is li al-Nashr wa al-Tawzi, 200 I), 273.

${ }^{50}$ Pada sistem Pemilu 2004 telah ada perubahan menyangkut tata pencobloan, penghitungan suara, penentuan daerah pemilihan, persyaratan pesita pemilu, penetapan pasangan caprescawapres, dan lembaga persyaratan pemilu. Lihat: Lili Zakiyah Munir, dkk, Perempuan, Politik \& Pemilu 2004: Buku Panduan Untuk Pemilih, Jombang: Center for Pesantren and Demokrasi, 2004), 25, 34.

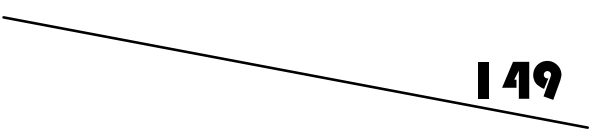


terpilih berdasarkan nomor urut. Artinya, terobosan BPP tetap mandul dalam tataran aplikasinya, para elit partai tetap dominan, dan simbol partai tetap menonjol, sedangkan caleg sendiri tidak diketaui oleh para pemilihnya, bahkan potensi antar caleg tidak terlalu menonjol, karena para pemilih hanya cukup mencoblos simbol partai atau boleh nama calon saja.

Selain mandul, penerapan UU No. 12/2003 pada pemilu 2004 berimplikasi pada kecenderungan caleg yang lebih loyal kepada elit parpol ketimbang kepada pemilih yang diwakilinya. Konsekuensinya, anggota legislatif lebih mengabdi dan setia kepada para petinggi parpol ketimbang kepada rakyat yang memilihnya.

Selain itu, implikasi dari suara terbanyak, setidaknya dapat memutus mata rantai oligarki ${ }^{51}$ pimpinan parpol dalam penentuan caleg, meskipun tidak serta-merta memberantas semuanya. Namun, kewenangan parpol yang semula cukup besar dalam penentuan caleg terpilih, otomatis akan berkurang. Suara terbanyak juga berpotensi untuk memutus mata rantai praktik jual beli nomor urut yang diduga kuat menjadi tradisi parpol. Untuk jangka panjang, mekanisme ini juga akan mendorong pergeseran dari oligarki pimpinan parpol pada kedaulatan rakyat sebagai pemilih.

\section{Suara Terbanyak dalam Pembacaan Siyasah Dusturiyah}

Hak-hak sipil yang ditegakkan atas dasar pemilihan, perjanjian (Baiat) dan musyawarah (Syura), merupakan bagian penting dalam siyasah dusturiyah, yang memiliki relevansi dengan tanggung jawab pemimpin di hadapan umat, dan hak setiap rakyat (Umat) ${ }^{52}$ yang disebut dengan Hifd al-Ummah (hak umat) tanpa melihat perbedaan jenis kelamin dan teritorial. Karena

51 Oligarki adalah kepemerintahan yang dipegang oleh beberapa orang dari golongan elit.

${ }^{52}$ Samir Aliyah, 82. 
memang istilah Ummah (umat) 53 dalam terminologi Islam cakupannya sangat luas, ${ }^{54}$ melewati batas-batas wilayah yang sempit dan dalam waktu yang sama juga menghormati perbedaanperbedaan tersebut. Karena perlindungan terhadap hak-hak umat merupakan tujuan hukum Islam. ${ }^{55}$

Artinya, hukum tidak pandang bulu atau memilah-milih dengan alasan perbedaan-perbedaan apapun, ${ }^{56}$ karena Negara yang Islami adalah memberikan perlakuan dan penghormatan terhadap hak-hak dan kebebasan manusia sebagai penentu bagi kemuliaan umat. ${ }^{57}$

Oleh karena sistem nomor urut berpotensi menghilangkan hak-hak umat sebagai warga negara, sedangkan mekanisme suara terbanyak dapat merealisasikan hak-hak umat yang berupa persamaan dimuka hukum, dan kebebasan untuk memilih dan dipilih yang dikenal dengan istilah Hifd al-ummah, yaitu; Hifd alNafs, yaitu memberikan jaminan terhadap hak-hak asasi manusia (hurriyah al-syahsiyah); jaminan mengeluarkan pendapat (hurriyah $a l-r a^{\prime} y$ ), dan hak untuk mendapatkan persamaan (al-musyawah) di muka hukum dan pemerintahan.

Artinya mekanisme suara terbanyak lebih mendekatkan pada kemaslahatan umat, karena apabila wakil rakyat itu tidak pandai memelihara dukungan publik, memungkinkan muncul "kritik" dari publik atau setidaknya tidak terpilih lagi di pemilu berikutnya, karena popularitasnya tergantung dari reputasi yang

53 Menurut Quraish Shihab,dalam kata "ummah" terselip makna-makna yang cukup dalam. "Ummah" mengandung arti gerak dinamis, arah, waktu, jalan arah, harus jelas jalannya, serta harus bergerak maju dengan gaya dan cara tertentu, dan pada saat yang sama membutuhkan waktu untuk mencapainya. Lihat: M. Quraish Shihab, Wawasan al-Qur'an; Tafsir Maudhu'i Atas Pelbagai Persoalan Umat, (Bandung: Mizan, 1996), 327.

${ }^{54}$ Muhammad Iqbal, Fiqh Siyasah; Kontekstualisasi Doktrin Politik Islam, (Jakarta: Media Pratama, 2007), 182

55 Muhamad Abu Zahroh, (et. Al), Saefullah Ma'shum, Ushul Fiqh, (Jakarta: Pustaka Firdaus, 2007), 425.

${ }^{56}$ Beni Ahmad Saebani, Filsafat Hukum Islam, (Bandung: Pustaka Setia,), 243.

${ }^{57}$ Samir Aliyah, Sistem Pemerintahan Peradilan, I 51.

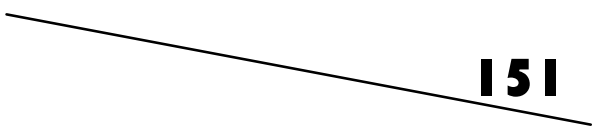


ia bangun, entah murah hati, jujur atau lihai. ${ }^{58}$ Kualitas reputasi yang dihasilkan tentunya akan dinilai orang lain (konstituen/rakyat) dan bahkan dibicarakan. Kenyataan dialektis semacam ini, tentunya akan mendorong anggota legislatif untuk lebih aspiratif terhadap kepentingan konstituen, sehingga dapat membuka ruang partisipasi ${ }^{59}$ dalam proses pengambilan keputusan di parlemen.

Realitas seperti di atas, pastinya tumbuh dari kesadaran politik rakyat yang dapat menjadi unsur dinamisator dalam perwujudan kesejahteraan rakyat, sehingga kesadaran rakyat terhadap hak-hak mereka harus tetap dihormati. Sesuai dengan kaidah: "La Yunkiru Taghyir al-Ahkam Bitaghyir al-Zaman."60 Maksudnya, apabila UU sebelumya ternyata tidak sesuai dengan tuntunan perkembangan masyarakat, maka harus dirubah. Begitu juga Pasal 214 UU 10/2008 untuk pemenangan caleg harus diganti dengan mekanisme suara terbanyak, karena telah dianggap tidak mencerminkan kedaulatan rakyat dan prinsip demokrasi yang menjadi pilihan rakyat Indonesia.

Oleh karena itu, setiap Caleg yang ikut kontestasi dalam pemilu 2009 dengan sistem suara terbanyak harus berusaha keras secara intensif untuk memikat hati para konstituennya. Konsekuensinya, caleg harus menyediakan modal finansial dalam jumlah besar. Apalagi karakteristik pemilih yang cenderung pragmatis dan transaksional. Saperti Dapil yang terletak diperkotaan yang pada umumnya karakteristik pemilihnya cenderung pragmatis, tentu menjadi hal yang sangat berat bagi caleg, apalagi selain mereka harus bersaing dengan caleg dari

\footnotetext{
${ }^{58}$ Rebert Greene, The 48 Laws Of Power/48 Kekuasaan, alih bahasa, Amelia Listiani, (Jakarta: Karisma Publising - Group, 2007), 84.

${ }^{59}$ Partisipasi politik sebagai kegiatan warga negara yang bertujuan mempengaruhi pengambilan keputusan oleh pemerintah. Dan secara umum, semua kegiatan mempunyai tujuan mempengaruhi kebijakan, tak peduli apakah itu legal atau ilegal dari norma-norma yang berlaku di dalam sistem politik yang bersangkutan. Lihat: Samuel P. Huntington, Joan M. Nelson, Partisipasi Politik Tak Ada Pilihan Mudah, alih bahasa, Hasan Basari, (Jakarta: Sangkala Pulsar, 1984), 5-7.

60 Muhammad Iqbal, Fiqh Siyasah; Kontekstualisasi Doktrin Politik Islam, 16.
} 
parpol lain, juga harus merebut suara dari caleg dalam satu partai. Dalam situasi seperti ini, maka para caleg harus berusaha ekstra keras dengan mengeluarkan ongkos politik, psikologis, dan ekonomis yang tidak kecil.

Dengan demikian, sistem nomor urut maupun mekanisme suara terbanyak sebenarnya sama-sama menimbulkan mafsadad, disamping juga sama-sama ada manfaatnya. Di dalam posisi yang demikian, berdasarkan kaidah: "Dar'u al-Mafasid Muqaddamatun 'Ala Jalbi al-Masalih." 61 Artinya, apabila pada waktu yang sama kita dihadapkan kepada dua pilihan (mafsad-maslahah), maka yang harus didahulukan adalah menolak mafsadat. ${ }^{62}$ Dengan kata lain, sebuah implementasi perundang-undangan yang dapat menimbulkan hal-hal yang bertolak belakang, ${ }^{63}$ disatu sisi menimbulkan keuntungan tapi disisi yang lain menimbulkan bahaya, maka yang didahulukan adalah menghindari bahaya.

Dengan demikian, efek negatif yang ditimbulkan sistem nomor urut lebih besar ketimbang suara terbanyak, karena berimplikasi pada kepentingan mayoritas. Pendek kata, pemenangan caleg yang berdasarkan nomor urut berefek negatif pada rakyat secara umum, yaitu pemangkasan terhadap hak-hak rakyat, dan pembatasan pada kebebasan warga Negara untuk memilih dan dipilih. Sedangkan suara terbanyak dapat memberi ruang yang lebih luas terhadap aspirasi-aspirasi rakyat, sehingga mafsadatnya hanya bagi orang-orang yang mempunyai otoritas dalam partai politik ataupun terhadap Caleg-caleg ambisius saja.

Kualifikasi dari implikasi sistem nomor urut dan suara terbanyak seperti di atas, berdasarkan kaidah: "al-Maslahah al'Ammah Muqaddamatun 'Ala Maslahat al-Khasah."64 Atinya esensialnya, melindungi kemaslahatan yang luas, lebih utama dari pada bagi segelintir orang saja.

${ }^{61}$ Djazuli, Kaidah-kaidah Fikih, 164.

62 lbid.

${ }^{63}$ Muhammad lqbal, Fiqh Siyasah, 16.

${ }^{64}$ Muhammad lqbal, Fiqh Siyasah, 18.

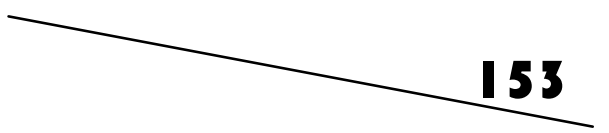


Sedangkan mekanisme suara terbanyak berpotensi untuk mendorong terjadinya pergeseran pola hubungan anggota legislatif dengan para pemilih masing-masing caleg dari tipe partisan ke tipe delegasi, yaitu adanya keterikatan antara wakil rakyat dengan pemilihnya. Oleh karenanya, mekanisme suara terbanyak akan berdampak positif lebih luas, yaitu dapat meningkatkan kualitas keterwakilan anggota parlemen, karena akan lebih mendekatkan pemilih dengan wakil-wakilnya, dan akan mendorong anggota legislatif untuk tetap terus bersinergi dengan kepentingan konstituen di dapil yang diwakilinya.

Dengan demikian, mekanisme suara terbanyak lebih relevan untuk diterapkan bagi penentu kemenangan anggota legislatif, karena lebih memungkinkan bagi perealisasian tujuan syariat, yaitu mengusahakan dan merealisasikan kemaslahatan umat/rakyat dalam kehidupan berbangsa dan bernegara.

\section{Penutup}

1. Mekanisme nomor urut bagi pemenangan anggota legislatif bertentangan dengan norma-norma atau dengan makna substantif kedaulatan dan persamaan hak bagi rakyat yang terkandung dalam UUD 1945, yang juga dibenarkan oleh prinsip-prinsip Syariat Islam.

2. Implikasi mekanisme suara terbanyak adalah dapat membatalkan Pasal 214 UU 10/2008 tentang mekanisme nomor urut, suara terbanyak juga berpotensi memutus mata rantai oligarki dan jual beli nomor urut dalam tubuh partai politik, dapat membuka ruang ekspresi politik bagi warga negara, dan mendorong terjadinya pola hubungan timbal balik antara anggota legislatif dengan konstituenya, serta dapat meningkatkan kualitas keterwakilan anggota parlemen.

3. Mekanisme suara terbanyak memiliki efek positif yang lebih luas bukan orang perorangan ataupun kelompok, dan lebih mendekatkan pada Maslahah al-'Ammah, serta relevan atau sesuai dengan tujuan syariat dengan mewujudkan Hifd al- 
ummah dalam kategori Hifd al-Nafs yaitu, hurriyah al-syahsiyah berupa hurriyah al-ra'y danal-Musyawah, yaitu persamaan hak di muka hukum dan pemerintahan.

\section{Daftar Rujukan}

Aliyah, Samir, Sistem Pemerintahan Peradilan dan Adat dalam Islam, Terj. Abdurrahman Kasdi, Jakarta: KHALIFA, 2004.

'Asyur, Muhammad Thahir Ibn, Maqhasyid al-Syari'ah al-Islamiyah, Dar al-Mafa'is li al-Nashr wa al-Tawzi, 2001.

Arifin, Miftahul \& Haq, Faishal, Ushul Figh I, Surabaya: Biro Penerbitan dan Pengembangan Fakultas Syari'ah IAIN Sunan Ampel, 1995.

Budiarjo, Meriam, Dasar-dasar Ilmu Politik, Jakarta: Pustaka Utama, 1972.

Djaelani, Abdul Qadir, Negara Ideal Menurut Konsepsi Islam, Surabaya: Bina Ilmu, 2005.

Djamil, Fathurrahman, Filsafat Hukum Islam, Jakarta: Logos, 1999.

Djazuli, A, Kaidah-kaidah Fikih; Kaidah-kaidah Hukum Islam dalam Menyelesaikan Masalah-masalah yang Praktis, Jakarta: Kencana, 2007.

-------, Fiqh Siyasah; Implementasi Kemaslahatan Umat dalam Ramburambu Syariah, Jakarta: Putra Grafika, 2007.

-------, dan, Aen, Nurol, Ushul Figh; Metodologi Hukum Islam, Jakarta: RajaGrafindo Persada, 2000.

Departemen Pendidikan Nasional, Kamus Besar Indonesia, Jakarta: Gramedia Pustaka Utama, 2008.

Greene, Robert, The 48 Laws Of Power, Terj. Amelia Listiana, Jakarta: KARISMA Publising-Group, 2007.

Hidayat, Komaruddin\& Azra, Azumardi, Pendidikan Kewargaan; Civic Education, Jakarta: Kencana Prenada Group; ICCE UIN Syarif Hidayatullah, 2008.

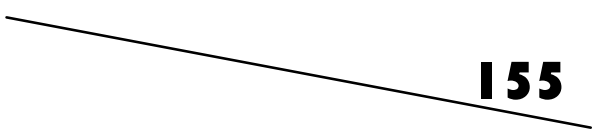


Huntington, Samuel P., Nelson, Joan M., Partisipasi Politik Tak Ada Pilihan Mudah, Terj. Hasan Basari, Jakarta: Sangkala Pulsar, 1984.

Jindan, Khalid Ibrahim, Tori Politik Islam; Telaah Kritis Ibnu Taimiyah Tentang Pemerintahan Islam, Yogyakarta: Risalah Gusti, 1995.

Iqbal, Muhammad, Fiqh Siyasah; Kontekstualisasi Doktrin Politik Islam, Jakarta: Media Pratama, 2007.

Al-Jauziyah, Ibnu Qayyim, (et.), Muhammad Jamil Ghozi, Hukum Acara Peradilan Islam, Terj.Adnan Qohar, Anshoruddin, Yogyakarta: Pustaka Pelajar, 2006.

Kelsen, Hans, Teori Umum Tentang Hukum dan Negara,Terj. Raisul Muttaqien, Bandung: Nusa Media \& Nuansa, 2006.

-------, Teori Hukum Murni; Dasar-dasar ilmu Hukum Normatif, Terj. Raisul Muttaqien, Jakarta: Nusa Media, 2008.

Khallaf, Abdul Wahhab, al-Siyasah al-Syar'iyah aw Niz am al-Daulah al-Islamiyah fi al-Syu'un al-Dusturiyah wa al-Kharijiyah wa alMaliyah, Kairo: Dar al-Anshar, 1977.

Leonard W. Levy, (terj), Judicial Review; Sejarah Kelahiran, Wewenang dan Fungsinya dalam Negara Demokrasi, Jakarta: Media Pratama, 2008.

Al-Mawardi, Imam, Al-Ahkam As-Sultaniyyah; Hukum-hukum Penyelenggaraan Negara dalam Syari'ah Islam, Terj. Fadli, Jakarta: Darul Falah, 2007.

al-Maududi, Abul A'la, Tadwin al-Dustur al-Islami, Darul Fiqri, tt. al-Khilafah Wa al-Muluk, Kuwait: Dar al-Qalam, 1978.

Manan, Abdul, Reformasi Hukum Islam Di Indonesia, Jakarta: Rajagrafindo Persada, 2006.

Mu'allim, Amir dan Yusdani, Konfigurasi Pemikiran Hukum Islam, Bandung, Pustaka, 2008.

Munir, Lili Zakiyah, dkk, Perempuan, Politik \& Pemilu 2004: Buku Panduan Untuk Pemilih, Jombang: Center for Pesantren and Demokrasi, 2004. 
Pulungan, J. Suyuti, Fiqih Siyasah: Ajaran Sejarah dan Pemikiran, Jakarta: PT. Grafindo Persada, 1994.

Ash-Shiddieqy, TM. Hasbi, Pengantar Figh Mu'amalah, Semarang: Pustaka Rezki Putera, 2007.

Al-Qardhawy, Yusuf, Fiqih Daulah dalam Perspektif Al-Qur'an dan Sunnah, Terj. Kathur Suhardi, Jakarta: Pustaka Al-Kautsar, 1997.

Riewanto, Agust, Ensiklopedi Pemilu; Analisis Kritis Instropektif Pemilu 2004 Menuju Agenda Pemilu 2009, Yogyakarta: Fajar Pustaka, 2007.

Saebani, Beni Ahmad, Filsafat Hukum Islam, Bandung: Pustaka Setia, 2007.

-------, Fiqih Siyasah: Pengantar Ilmu Politik Islam, Bandung: Pustaka Setia, 2007.

Salim, Abdul Muin, Figh Siyasah; Konsepsi Kekuasaan Politik dalam alQur'an, Jakarta: Raja Grafindo Persada, 2002.

Sinaga, Budiman N.PD, Hukum Konstitusi, Yogyakarta: Kurnia Kalam Semesta, 2005.

Shihab, M. Quraish, Wawasan al-Qur'an; Tafsir Maudhu'i Atas Pelbagai Persoalan Umat, Bandung: Mizan, 1996.

Sjadzali, Munawwir, Islam dan Tata Negara, Jakarta: UI Press, 1990.

Sukarja, Ahmad, Ensiklopedi Tematis Dunia Islam, Fikih Siyasah, ttp. Ajaran: Ichtiar Van Hoeve, 2001.

Surbakti, Ramlan, Perekayasaan Sistem Pemilihan Umum Untuk Pembangunan Tata Politik Demokratis, Jakarta: Kemitraan, 2008.

Syarifuddin, Amir, Ushul Figh, Jakarta: Kencana, 2008.

Al-Syatibi, Abi Ishaq, al-Muwafaqot fi Ushul al-Syariah, Bairut: Dar al-Kutu al-Ilmiyah, ttp.

Tantawi, Muhammad Sayyid, Ijtihad dalam Teologi Keselarasan, Surabaya: JP BOOKS, 2005.

Thalib, Dahlan, dkk, Teori dan Hukum Konstitusi, Jakarta: Raja Grafindo Persada, 1999.

Tutik, Titik Triwulan, Pokok-pokok Hukum Tata Negara, Jakarta: Prestasi Pustaka, 2006.

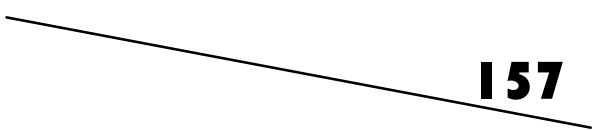


Usman, Suparman, Hukum Islam; Asas-asas dan Pengantar Studi Hukum Islam dalam Tata Hukum Indonesia, Jakarta: Gaya Media Pratama, 2001.

Yan Pratama, Puspa, Kamus Hukum, Semarang: Aneka Ilmu, 1977.

Zahroh, Muhammad Abu, Ushul Fiqih, Terj. Saefullah Ma'sum, dkk, Jakarta: Pustaka Firdaus, 2007.

Zaidan, Abdul Karim, al-Wajiz Fi Usul Figh, Maktabah al-Batsair, 1994.

Zallum, Abdul Qadim, Nidzam al-Hukmi Fi al-Islami: Bairut. Dar alUmmah, cet. Ke-6, Terj, Moh. Maghfur Wachid, Sistem Pemerintahan Islam, Bangil: Al-Izzah, 2007.

Dokumen Putusan Mahkamah Konstitusi N0.22-24/PUU-VI/2008.

Undang-undang Badan Peradilan, Bagian Ketiga Undang-undang Republik Indonesia No.24/2003.

Undang-undang Mahkamah Konstitusi Nomor 24 Tahun 2003) dan Pedoman Beracara dalam Perselisihan Hasil Pemilihan Umum Kepala Daerah (Peraturan MK No. 15 Tahun 2008), Pedoman Beracara dalam Sengketa Kewenangan Konstitusional Lembaga Negara (Peraturan MK No. 08/PMK/2006), Pedoman Beracara dalam Perkara Pengujian UU (Peraturan MK No. 06/PMK/2005), Surabaya: Asa Mandiri, 2009.

UUD 1945 Republik Indonesia; Amandemen I, II dan IV.

Undang-undang Pemilu Nomor 10 Tahun 2008.

Gatra, 23 April 2009.

Harian Medan Bisnis, 24 Desember 2008.

Suara Karya, 24-08-2008.

Suara Merdeka, 10 Maret 2009. 